\title{
To Study the Nutrient Status in Soil and Plant after the Harvesting of the Tuber Crops under Three-tier Agroforestry System
}

\author{
Vishnu K. Solanki* \\ Department of Agroforestry, College of Agriculture, JNKVV Campus, Ganjbasoda, Madhya Pradesh (464 221), India
}

Corresponding Author

Vishnu K. Solanki

e-mail: drvishnu@hotmail.com

\author{
Article History \\ Article ID: $3 \mathrm{C0270}$ \\ Received in $29^{\text {th }}$ September, 2017 \\ Received in revised form $25^{\text {th }}$ November, 2017 \\ Accepted in final form $4^{\text {th }}$ December, 2017
}

\begin{abstract}
An experiment was carried out to find out the nutritional status in soil and plants of tuber crops under Sapota-Jatropha based three-tier agroforestry system at the Agronomy Farm (Block-E), ASPEE College of Horticulture and Forestry, Navsari Agricultural University, Navsari (Gujarat) during rainy season 2011 and 2012. Statistically, experiment was laid out in randomized block design with six treatments and four replications. The seven years old plantation of Sapota (Manilkara acharas (Mill.) Fosberg) planted at $10 \times 10 \mathrm{~m}$ spacing, with five year old plantation of Jatropha (Jatropha curcas L.) which was planted at $2.5 \times 2.5 \mathrm{~m}$ spacing used for intercropping study. Three tuber medicinal plants viz., Kalihari (Gloriosa superba L.), Kali musli (Curculigo orchioides Gaertn) and Safed musli (Chlorophytum borivilianum Ker.) were selected for the present study. The observations viz. organic carbon, N, P, K, Ca, Mg, Fe, Mn, Zn and Cu in soil were analyzed after harvesting. Intercropping of Kalihari, Kali musli and Safed musli recorded higher nutrients viz., organic carbon, N, P, K, Ca, Mg, Fe, Mn, Zn and Cu in soil as compared to sole crop. Similarly higher organic carbon, N, P, K, Ca, Mg, Fe, Mn, Zn and Cu in plant was recorded under Sapota-Jatropha as compared to sole crop of kalihari, kali musli and safed musli. The trend was same in both the years as well as in pooled.
\end{abstract}

Keywords: Intercropping, kalihari, kali musli, nutrient, safed musli

\section{Introduction}

The medicinal plants growing in forests require partial shade, moist soils rich in organic matter, high relative humidity and mild temperatures. Cultivation of such medicinal plants can be taken up in thinned forests, cleared forest patches, and as intercrops in orchards and new forest plantations (Venugopal et al., 2008). There are number of indigenous under storey herbs and shrubs that can be produced as a part of forest farming or in new forest plantation to improve economic return as well as soil health from the forests in India. Newly established forest plantations can be intercropped with medicinal plants similar to food crops until the trees cover the ground. The participation of the local people with the right to share benefits of the plantations, especially ownership to crops, has helped government to establish plantations without conflict with the local people in many Asian countries. The same approach can be employed for the cultivation of medicinal plants in the new plantations. In the rehabilitation of degraded forest lands, participating, planning and implementation with local communities and economic benefits from an early stage onwards will ensure commitment of the people. The intensity of shade experienced by the under storey medicinal plants growing in forests and tree plantation affects their growth and chemical composition. In recent year's attention has focused on the diversified medicinal plant production system for maximizing utilization of resources as compared to the monoculture cropping systems. This allows judicious use of the internal spaces of the trees and crops promoting diversification, enhancing per capita land productivity and cultivation of the crops in demand (Willey, 1979). Medicinal plants in the nature are now under great pressure due to their excessive collection and exploitation (Laloo et al., 2000). Continuous exploitation of several medicinal plant species and substantial loss of their habitats have resulted in the population decline of many high value medicinal plant species over the years (Kala and Sajwan, 2003). As such there is no sufficient work on agroforestry system of horticultural, silvicultural and medicinal crops in India with regards to soil health and leaf nutrition.

\section{Materials and Methods}

The present investigation was conducted under rainfed conditions during kharif season 2011 and 2012 at Navsari Agricultural University, Navsari, Gujarat. The climate of the area is characterized by three well defined seasons viz., monsoon, winter and summer. The seven year old plantation of Sapota (Manilkara acharas (Mill) Fosberg.) at $10.0 \mathrm{~m} \times 10.0$ 
$m$ spacing, inter cropped with five year old plantation of Jatropha (Jatropha curcus L.) at $2.5 \mathrm{~m} \times 2.5 \mathrm{~m}$ spacing were used for intercropping study. Three tuber medicinal plants viz Kalihari (Gloriosa superba L.) at $30 \mathrm{~cm} \times 60 \mathrm{~cm}$, Kali musli (Curculigo orchioides Gaertn) at $30 \mathrm{~cm} \times 30 \mathrm{~cm}$ and Safed musli (Chlorophytum borivilianum Ker.) at $30 \mathrm{~cm} \times 30 \mathrm{~cm}$ were selected for the present study. The statistically, experiment was laid out in randomized block design with replicated four times with following treatments i.e. $\mathrm{T}_{1}$-Manilkara achras+Jatropha curcas+Gloriosa superba, $\mathrm{T}_{2}$-Manilkara achras+Jatropha curcas+Curculigo orchioides, $\mathrm{T}_{3}$-Manilkara achras+Jatropha curcas+Chlorophytum borivilianum, $\mathrm{T}_{4}$-Gloriosa superba sole, $\mathrm{T}_{5}$-Curculigo orchioides sole, $\mathrm{T}_{6}$-Chlorophytum borivilianum sole. Farm Yard manure was applied@ 20t/ha to all the plots uniformly and was incorporated into the soil at the time of land preparation. Nitrogen, phosphorus and potash were applied at the rate of 50:50:70 Kg ha-1 (for Kalihari), 25:15:10 kg ha-1 (for Kali musli), 60:65:20 kg ha-1 (for Safed musli) respectively. All intercultural operations were done when it was necessary. Soil analysis techniques are:

\subsection{Nutrient analysis of soils:}

Representative soil sample $(0-30 \mathrm{~cm})$ from the experimental site were collected before and after the experiment and used for determining the basic physico-chemical properties. The soil samples were dried in shade, processed and used for further analysis.

\subsection{Nutrient analysis of plants:}

Plant samples used for studying dry matter production were used for estimating nutrient content in whole plant. The samples were powdered and stored in plastic container and were used for further analysis.

\subsection{Statistical analysis}

The collected data were analyzed statistically as per the appropriate procedure by using randomized block design in four replicates for each treatment as described by Panse and Sukhatme (1978) and the treatment means were compared by means of critical differences at 5 per cent level of probability.

\section{Results and Discussion}

\subsection{Nutrient status in soil after the harvesting of the tuber crops}

\subsubsection{Organic carbon status $\left(\mathrm{g}^{-1}\right)$ in soil}

The result revealed that status of organic carbon in soil at harvest was significant during both the years of experimentation and in their pooled data (Table 1). In the first year, data indicated that intercrop of kalihari, kali musli and safed musli $\left(T_{1}, 6.50 \mathrm{~g} \mathrm{~kg}^{-1}, \mathrm{~T}_{2}, 6.53 \mathrm{~g} \mathrm{~kg}^{-1}\right.$ and $\mathrm{T}_{3,} 6.64 \mathrm{~g} \mathrm{~kg}^{-}$ $\left.{ }^{1}\right)$ recorded significantly higher organic carbon status in soil

Table 1: Organic carbon and major nutrients available in soil at harvest of tuber crops as influenced by Sapota-Jatropha three-tier agroforestry system

\begin{tabular}{|c|c|c|c|c|c|c|c|c|c|c|c|c|}
\hline \multirow{2}{*}{$\begin{array}{l}\text { Treat- } \\
\text { ment }\end{array}$} & \multicolumn{3}{|c|}{ Organic carbon $\left(\mathrm{g} \mathrm{kg}^{-1}\right)$} & \multicolumn{3}{|c|}{ Nitrogen (kg ha-1) } & \multicolumn{3}{|c|}{ Phosphorus (kg ha-1 $)$} & \multicolumn{3}{|c|}{ Potassium $\left(\mathrm{kg} \mathrm{ha}^{-1}\right)$} \\
\hline & 2011 & 2012 & Pooled & 2011 & 2012 & Pooled & 2011 & 2012 & Pooled & 2011 & 2012 & Pooled \\
\hline $\mathrm{T}_{1}$ & $\begin{array}{c}6.5 \\
(11.49)^{*}\end{array}$ & $\begin{array}{c}6.55 \\
(11.97)^{*}\end{array}$ & $\begin{array}{c}6.53 \\
(11.82)^{*}\end{array}$ & $\begin{array}{c}247.48 \\
(13.52)^{*}\end{array}$ & $\begin{array}{c}250.53 \\
(13.88)^{*}\end{array}$ & $\begin{array}{c}249.01 \\
(13.70)^{*}\end{array}$ & $\begin{array}{c}34.23 \\
(9.96)^{*}\end{array}$ & $\begin{array}{c}34.73 \\
(9.80)^{*}\end{array}$ & $\begin{array}{c}34.48 \\
(9.88)^{*}\end{array}$ & $\begin{array}{c}411.86 \\
(15.51)^{*}\end{array}$ & $\begin{array}{c}432.11 \\
(17.80)^{*}\end{array}$ & $\begin{array}{c}421.99 \\
(16.67)^{*}\end{array}$ \\
\hline $\mathrm{T}_{2}$ & $\begin{array}{c}6.53 \\
(10.68)^{*}\end{array}$ & $\begin{array}{c}6.56 \\
(10.62)^{*}\end{array}$ & $\begin{array}{c}6.55 \\
(10.83)^{*}\end{array}$ & $\begin{array}{c}259.24 \\
(18.36)^{*}\end{array}$ & $\begin{array}{c}261.99 \\
(18.00)^{*}\end{array}$ & $\begin{array}{c}260.62 \\
(18.18)^{*}\end{array}$ & $\begin{array}{c}35.26 \\
(12.98)^{*}\end{array}$ & $\begin{array}{c}35.76 \\
(12.77)^{*}\end{array}$ & $\begin{array}{c}35.51 \\
(12.87)^{*}\end{array}$ & $\begin{array}{c}416.98 \\
(13.72)^{*}\end{array}$ & $\begin{array}{c}437.23 \\
(15.92)^{*}\end{array}$ & $\begin{array}{c}427.11 \\
(14.84)^{*}\end{array}$ \\
\hline $\mathrm{T}_{3}$ & $\begin{array}{c}6.64 \\
(11.78)^{*}\end{array}$ & $\begin{array}{c}6.68 \\
(12.08)^{*}\end{array}$ & $\begin{array}{c}6.66 \\
(11.93)^{*}\end{array}$ & $\begin{array}{c}269.85 \\
(22.97)^{*}\end{array}$ & $\begin{array}{c}272.6 \\
(22.54)^{*}\end{array}$ & $\begin{array}{c}271.23 \\
(22.76)^{*}\end{array}$ & $\begin{array}{c}37.5 \\
(20.15)^{*}\end{array}$ & $\begin{array}{c}38.03 \\
(19.52)^{*}\end{array}$ & $\begin{array}{c}37.76 \\
(19.80)^{*}\end{array}$ & $\begin{array}{l}437.12 \\
(15.99)^{*}\end{array}$ & $\begin{array}{c}447.37 \\
(15.49)^{*}\end{array}$ & $\begin{array}{c}442.25 \\
(15.74)^{*}\end{array}$ \\
\hline $\mathrm{T}_{4}$ & 5.83 & 5.85 & 5.84 & 218 & 220 & 219 & 31.13 & 31.63 & 31.38 & 356.56 & 366.81 & 361.69 \\
\hline $\mathrm{T}_{5}$ & 5.9 & 5.93 & 5.91 & 219.02 & 222.02 & 220.52 & 31.21 & 31.71 & 31.46 & 366.67 & 377.17 & 371.92 \\
\hline $\mathrm{T}_{6}$ & 5.94 & 5.96 & 5.95 & 219.45 & 222.45 & 220.95 & 31.21 & 31.82 & 31.52 & 376.87 & 387.37 & 382.12 \\
\hline SEm \pm & 0.198 & 0.219 & 0.148 & 8.734 & 12.668 & 7.693 & 1.146 & 1.529 & 0.955 & 12.336 & 19.323 & 11.462 \\
\hline CD & 0.6 & 0.66 & 0.43 & 26.32 & 38.18 & 22.22 & 3.45 & 4.61 & 2.76 & 37.18 & 58.23 & 33.1 \\
\hline
\end{tabular}

$\mathrm{T}_{1}$ : Kalihari Intercrop; $\mathrm{T}_{2}$ : Kali musli Intercrop; $\mathrm{T}_{3}$ : Safed musli Intercrop; $\mathrm{T}_{4}$ : Kalihari Sole; $\mathrm{T}_{5}$ : Kali musli Sole; $\mathrm{T}_{6}$ : Safed musli Sole; $C D: C D(p=0.05)$; *Figure in parenthesis indicates percentage increases over respective sole cropping

which was followed by sole kalihari, kali musli and safed musli $\left(\mathrm{T}_{4}, 5.83 \mathrm{~g} \mathrm{~kg}^{-1}, \mathrm{~T}_{5}, 5.90 \mathrm{~g} \mathrm{~kg}^{-1}\right.$ and $\mathrm{T}_{6}, 5.94 \mathrm{~g} \mathrm{~kg}^{-1}$ ) respectively. During second year at harvest, significantly higher organic carbon status in soil was observed in kalihari when it was grown under Sapota-Jatropha $\left(T_{1}, 6.55 \mathrm{~g} \mathrm{~kg}^{-1}\right)$ cropping system. Pooled analysis was observed the same trend of organic carbon in soil as per the trend of first year result. This may be due to more litterfall from trees and it may also be due to decomposition of litter. This is supported by Jaimini et al. (2006), Aaron and Adams (2016), Deng et al. (2017) and Shehnaz et al. (2015). 


\subsubsection{Available nitrogen status $\left(\mathrm{kg} \mathrm{ha}^{-1}\right)$ in soil}

The available nitrogen status in the soil was recorded higher when tuber crops are grown under Sapota-Jatropha as compared to respective sole cropping (Table 1). During first year, significantly higher nitrogen in soil was recorded when kalihari, kali musli and safed musli grown under SapotaJatropha $\left(T_{1}, 247.48 \mathrm{~kg} \mathrm{ha}^{-1}, T_{2}, 259.24 \mathrm{~kg} \mathrm{ha}^{-1}\right.$ and $T_{3}, 269.85$ $\mathrm{kg} \mathrm{ha}^{-1}$ ) cropping system. During second year, maximum nitrogen in soil was recorded when kalihari grown under Sapota-Jatropha $\left(T_{1}, 250.53 \mathrm{~kg} \mathrm{ha}^{-1}\right)$. Pooled analysis showed the same trend of nitrogen status in soil is evident as per the trend of first year result. This is supported by Rajesh and Baghel (2014), Biar et al. (2017), Shehnaz et al. (2015) and Samritika et al. (2015).

\subsubsection{Available phosphorus status $\left(\mathrm{kg} \mathrm{ha}^{-1}\right)$ in soil}

From Table 1, it can be seen that in first year of study, kalihari was recorded maximum phosphorus in soil when these grown under Sapota-Jatropha $\left(T_{1}, 34.23 \mathrm{~kg} \mathrm{ha}^{-1}\right)$ and in second year, kalihari and kali musli observed maximum potassium in soil when grown under Sapota-Jatropha $\left(T_{1}, 34.73 \mathrm{~kg} \mathrm{ha}^{-1}\right.$ and $\mathrm{T}_{2} 35.76 \mathrm{~kg} \mathrm{ha}^{-1}$, respectively) cropping system. An analysis of pooled mean data showed that, the significantly higher potassium in soil was recorded when kalihari grown under Sapota-Jatropha $\left(T_{1}, 34.48 \mathrm{~kg} \mathrm{ha}^{-1}\right)$ which was followed by sole kalihari $\left(\mathrm{T}_{4}, 31.38 \mathrm{~kg} \mathrm{ha}^{-1}\right)$. This is supported by Samritika et al. (2015), Aaron and Adams (2016) and Xue et al. (2016).

\subsubsection{Available potassium status $\left(\mathrm{kg} \mathrm{ha}^{-1}\right)$ in soil}

The available potassium status in the soil was recorded higher when tuber crops grown under Sapota-Jatropha as compared to sole cropping. It is evident from data presented in Table 1 that significantly higher potassium in soil was recorded when kalihari, kali musli and safed musli grown under SapotaJatropha ( $T_{1}, 411.86 \mathrm{~kg} \mathrm{ha}^{-1}, T_{2}, 416.98 \mathrm{~kg} \mathrm{ha}^{-1}$ and $T_{3,} 437.12 \mathrm{~kg}$ $\left.\mathrm{ha}^{-1}\right)$. In the second year and pooled data, the similar scenario of potassium in soil of all tuber crops (kalihari, kali musli and safed musli) was observed in the case of first year results. This may be due to higher microbial activities coupled with recycling of nutrients through leaf litter and more favorable physical condition viz., soil moisture, temperature under trees than sole. This is supported by Vanlalhluna and Sahoo (2010), Qaisar et al. (2007), Jaimini et al. (2006), Kaur et al. (2002) and Menezes et al. (2002) Shinde (2001), Biar et al. (2017) and Samritika et al. (2015).

\subsubsection{Secondary nutrients $(\mathrm{Ca}, \mathrm{Mg})\left(\mathrm{mg} \mathrm{kg}^{-1}\right)$ in soil}

The available calcium and magnesium status in the soil after the harvest of tuber crops between intercrops and sole crops showed in Table 2. All the tuber intercrops in their sole stand was recorded non-significant results in their respective

Table 2: Secondary nutrients available in soil at harvest of tuber crops as influenced by Sapota-Jatropha three-tier agroforestry system

\begin{tabular}{|c|c|c|c|c|c|c|}
\hline \multirow[t]{2}{*}{ Treatment } & \multicolumn{3}{|c|}{ Calcium (mg kg-1) } & \multicolumn{3}{|c|}{ Magnesium $\left(\mathrm{mg} \mathrm{kg}^{-1}\right)$} \\
\hline & 2011 & 2012 & Pooled & 2011 & 2012 & Pooled \\
\hline $\mathrm{T}_{1}$ & $6068.55(0.05)^{*}$ & $6071.55(0.06)^{*}$ & $6070.05(0.05)^{*}$ & $1813.35(0.10)^{*}$ & $1814.86(0.13)^{*}$ & $1814.11(0.12)^{*}$ \\
\hline $\mathrm{T}_{2}$ & $6069.12(0.05)^{*}$ & $6073.12(0.06)^{*}$ & $6071.12(0.05)^{*}$ & $1813.67(0.07)^{*}$ & $1815.68(0.12)^{*}$ & $1814.67(0.09)^{*}$ \\
\hline $\mathrm{T}_{3}$ & $6078.66(0.07)^{*}$ & $6079.16(0.05)^{*}$ & $6078.91(0.06)^{*}$ & $1814.58(0.07)^{*}$ & $1816.79(0.14)^{*}$ & $1815.68(0.10)^{*}$ \\
\hline $\mathrm{T}_{4}$ & 6065.67 & 6068.17 & 6066.92 & 1811.5 & 1812.53 & 1812.01 \\
\hline $\mathrm{T}_{5}$ & 6066.08 & 6069.58 & 6067.83 & 1812.35 & 1813.55 & 1812.95 \\
\hline $\mathrm{T}_{6}$ & 6074.44 & 6075.94 & 6075.19 & 1813.4 & 1814.16 & 1813.78 \\
\hline SEm \pm & 341.584 & 402.914 & 264.111 & 98.047 & 121.115 & 77.913 \\
\hline $\operatorname{CD}(p=0.05)$ & NS & NS & NS & NS & NS & NS \\
\hline
\end{tabular}

*Figure in parenthesis indicates percentage increases over respective sole cropping

intercropping systems during 2011, 2012 and in their mean data. This may be due to all these nutrients are not added in significant quantity via process of recycling by leaf litter added by Sapota-Jatropha. This is supported by Aaron and Adams (2016).

\subsubsection{Micro nutrients ( $\mathrm{Fe}, \mathrm{Mn}, \mathrm{Zn}, \mathrm{Cu})\left(\mathrm{mg} \mathrm{kg}^{-1}\right)$ in soil}

The data with respect to iron, manganese, zinc and copper status in soil of tuber crops under Sapota-Jatropha and sole crops of kalihari, kali musli and safed musli are furnished in Table 3. The results were found non-significant during both the year as well as in their mean data. Maximum iron, manganese, zinc and copper in soil was observed under Sapota-Jatropha as compared to sole cropping. Sapota-Jatropha as tree component has failed in altering the status of micronutrients through addition of leaf litter. This is supported by Xue et al. (2016).

\subsection{Nutrients content in tuber crops}

\subsubsection{Organic carbon content (\%)}

The data regarding to organic carbon content after the harvest of tuber crops during both the year and in their pooled analysis are presented in Table 4. The result reveals that organic carbon content after the harvest of tuber crops 


\begin{tabular}{|c|c|c|c|c|c|c|c|c|c|c|c|c|}
\hline \multirow{2}{*}{$\begin{array}{l}\text { Treat- } \\
\text { ment }\end{array}$} & \multicolumn{3}{|c|}{ Iron (mg kg-1) } & \multicolumn{3}{|c|}{ Manganese $\left(\mathrm{mg} \mathrm{kg}^{-1}\right)$} & \multicolumn{3}{|c|}{ Zinc $\left(\mathrm{mg} \mathrm{kg}^{-1}\right)$} & \multicolumn{3}{|c|}{ Copper $\left(\mathrm{mg} \mathrm{kg}^{-1}\right)$} \\
\hline & 2011 & 2012 & Pooled & 2011 & 2012 & Pooled & 2011 & 2012 & Pooled & 2011 & 2012 & Pooled \\
\hline $\mathrm{T}_{1}$ & $\begin{array}{c}4.88 \\
(0.41)^{*}\end{array}$ & $\begin{array}{c}4.89 \\
(0.62)^{*}\end{array}$ & $\begin{array}{c}4.88 \\
(0.41)^{*}\end{array}$ & $\begin{array}{c}10.18 \\
(0.59)^{*}\end{array}$ & $\begin{array}{c}10.19 \\
(0.49)^{*}\end{array}$ & $\begin{array}{c}10.18 \\
(0.49)^{*}\end{array}$ & $\begin{array}{c}0.69 \\
(6.15)^{*}\end{array}$ & $\begin{array}{c}0.69 \\
(6.15)^{*}\end{array}$ & $\begin{array}{c}0.69 \\
(6.15)^{*}\end{array}$ & $\begin{array}{c}2.69 \\
(1.51)^{*}\end{array}$ & $\begin{array}{c}2.69 \\
(0.75)^{*}\end{array}$ & $\begin{array}{c}2.69 \\
(1.13)^{*}\end{array}$ \\
\hline $\mathrm{T}_{2}$ & $\begin{array}{c}4.92 \\
(0.82)^{*}\end{array}$ & $\begin{array}{c}4.93 \\
(0.82)^{*}\end{array}$ & $\begin{array}{c}4.92 \\
(0.82)^{*}\end{array}$ & $\begin{array}{c}10.20 \\
(0.49)^{*}\end{array}$ & $\begin{array}{c}10.22 \\
(0.59)^{*}\end{array}$ & $\begin{array}{c}10.21 \\
(0.49)^{*}\end{array}$ & $\begin{array}{c}0.70 \\
(4.35)^{*}\end{array}$ & $\begin{array}{c}0.72 \\
(4.35)^{*}\end{array}$ & $\begin{array}{c}0.71 \\
(4.41)^{*}\end{array}$ & $\begin{array}{c}2.70 \\
(1.50)^{*}\end{array}$ & $\begin{array}{c}2.71 \\
(1.50)^{*}\end{array}$ & $\begin{array}{c}2.71 \\
(1.50)^{*}\end{array}$ \\
\hline $\mathrm{T}_{3}$ & $\begin{array}{c}5.02 \\
(1.01)^{*}\end{array}$ & $\begin{array}{c}5.04 \\
(1.20)^{*}\end{array}$ & $\begin{array}{c}5.03 \\
(1.21)^{*}\end{array}$ & $\begin{array}{c}10.22 \\
(0.49)^{*}\end{array}$ & $\begin{array}{c}10.24 \\
(0.59)^{*}\end{array}$ & $\begin{array}{c}10.23 \\
(0.59)^{*}\end{array}$ & $\begin{array}{c}0.75 \\
(4.17)^{*}\end{array}$ & $\begin{array}{c}0.76 \\
(4.11)^{*}\end{array}$ & $\begin{array}{c}0.76 \\
(5.56)^{*}\end{array}$ & $\begin{array}{c}2.73 \\
(1.87)^{*}\end{array}$ & $\begin{array}{c}2.75 \\
(2.23)^{*}\end{array}$ & $\begin{array}{c}2.74 \\
(2.24)^{*}\end{array}$ \\
\hline $\mathrm{T}_{4}$ & 4.86 & 4.86 & 4.86 & 10.12 & 10.14 & 10.13 & 0.65 & 0.65 & 0.65 & 2.65 & 2.67 & 2.66 \\
\hline $\mathrm{T}_{5}$ & 4.88 & 4.89 & 4.88 & 10.15 & 10.16 & 10.16 & 0.68 & 0.69 & 0.68 & 2.66 & 2.67 & 2.67 \\
\hline $\mathrm{T}_{6}$ & 4.97 & 4.98 & 4.97 & 10.17 & 10.18 & 10.17 & 0.72 & 0.73 & 0.72 & 2.68 & 2.69 & 2.68 \\
\hline SEm \pm & 0.191 & 0.286 & 0.172 & 0.341 & 0.443 & 0.280 & 0.034 & 0.030 & 0.023 & 0.083 & 0.098 & 0.064 \\
\hline$C D$ & NS & NS & NS & NS & NS & NS & NS & NS & 0.07 & NS & NS & NS \\
\hline
\end{tabular}

*Figure in parenthesis indicates percentage increases over respective sole cropping

Table 4: Organic carbon and major nutrients content in plant at harvest of tuber crops as influenced by Sapota-Jatropha three-tier agroforestry system

\begin{tabular}{|c|c|c|c|c|c|c|c|c|c|c|c|c|}
\hline \multirow{2}{*}{$\begin{array}{l}\text { Treat- } \\
\text { ment }\end{array}$} & \multicolumn{3}{|c|}{ Organic carbon $\left(\mathrm{g} \mathrm{kg}^{-1}\right)$} & \multicolumn{3}{|c|}{ Nitrogen $\left(\mathrm{kg} \mathrm{ha}^{-1}\right)$} & \multicolumn{3}{|c|}{ Phosphorus (kg ha-1) } & \multicolumn{3}{|c|}{ Potassium $\left(\mathrm{kg} \mathrm{ha}^{-1}\right)$} \\
\hline & 2011 & 2012 & Pooled & 2011 & 2012 & Pooled & 2011 & 2012 & Pooled & 2011 & 2012 & Pooled \\
\hline $\mathrm{T}_{1}$ & $\begin{array}{c}43.30 \\
(5.30)^{*}\end{array}$ & $\begin{array}{c}43.53 \\
(5.45)^{*}\end{array}$ & $\begin{array}{c}43.41 \\
(5.36)^{*}\end{array}$ & $\begin{array}{c}1.086 \\
(0.65)^{*}\end{array}$ & $\begin{array}{c}1.088 \\
(0.83)^{*}\end{array}$ & $\begin{array}{c}1.087 \\
(0.74)^{*}\end{array}$ & $\begin{array}{c}0.119 \\
(0.85)^{*}\end{array}$ & $\begin{array}{c}0.121 \\
(0.83)^{*}\end{array}$ & $\begin{array}{c}0.120 \\
(0.84)^{*}\end{array}$ & $\begin{array}{c}1.256 \\
(0.16)^{*}\end{array}$ & $\begin{array}{c}1.258 \\
(0.32)^{*}\end{array}$ & $\begin{array}{c}1.257 \\
(0.24)^{*}\end{array}$ \\
\hline $\mathrm{T}_{2}$ & $\begin{array}{c}42.49 \\
(5.41)^{*}\end{array}$ & $\begin{array}{c}42.68 \\
(5.30)^{*}\end{array}$ & $\begin{array}{c}42.58 \\
(5.34)^{*}\end{array}$ & $\begin{array}{c}1.226 \\
(0.91)^{*}\end{array}$ & $\begin{array}{c}1.228 \\
(0.99)^{*}\end{array}$ & $\begin{array}{c}1.227 \\
(0.90)^{*}\end{array}$ & $\begin{array}{c}0.126 \\
(2.44)^{*}\end{array}$ & $\begin{array}{c}0.127 \\
(2.42)^{*}\end{array}$ & $\begin{array}{c}0.127 \\
(3.25)^{*}\end{array}$ & $\begin{array}{c}1.335 \\
(0.07)^{*}\end{array}$ & $\begin{array}{c}1.336 \\
(0.15)^{*}\end{array}$ & $\begin{array}{c}1.336 \\
(0.15)^{*}\end{array}$ \\
\hline $\mathrm{T}_{3}$ & $\begin{array}{c}43.60 \\
(5.52)^{*}\end{array}$ & $\begin{array}{c}43.84 \\
(5.18)^{*}\end{array}$ & $\begin{array}{c}43.72 \\
(5.35)^{*}\end{array}$ & $\begin{array}{c}1.244 \\
(0.97)^{*}\end{array}$ & $\begin{array}{c}1.244 \\
(0.89)^{*}\end{array}$ & $\begin{array}{c}1.244 \\
(0.97)^{*}\end{array}$ & $\begin{array}{c}0.128 \\
(0.79)^{*}\end{array}$ & $\begin{array}{c}0.129 \\
(0.78)^{*}\end{array}$ & $\begin{array}{c}0.128 \\
(0.79)^{*}\end{array}$ & $\begin{array}{c}1.337 \\
(0.22)^{*}\end{array}$ & $\begin{array}{c}1.338 \\
(0.22)^{*}\end{array}$ & $\begin{array}{c}1.337 \\
(0.22)^{*}\end{array}$ \\
\hline $\mathrm{T}_{4}$ & 40.31 & 40.53 & 40.42 & 1.215 & 1.216 & 1.216 & 0.123 & 0.124 & 0.123 & 1.334 & 1.334 & 1.334 \\
\hline$T_{5}$ & 41.32 & 41.68 & 41.50 & 1.232 & 1.233 & 1.232 & 0.127 & 0.128 & 0.127 & 1.334 & 1.335 & 1.334 \\
\hline $\mathrm{T}_{6}$ & 1.353 & 1.970 & 1.195 & 0.040 & 0.042 & 0.029 & 0.005 & 0.006 & 0.004 & 0.040 & 0.059 & 0.036 \\
\hline SEm \pm & NS & NS & NS & 0.12 & 0.12 & 0.08 & NS & NS & NS & NS & NS & NS \\
\hline$C D$ & NS & NS & NS & NS & NS & NS & NS & NS & 0.07 & NS & NS & NS \\
\hline
\end{tabular}

*Figure in parenthesis indicates percentage increases over respective sole cropping

was non-significant during both the years of experimentation and in their pooled data. Organic carbon content being the basic building blocks are ought to be the same, however, in term of total biomass the organic carbon will differ greatly.

\subsubsection{Nitrogen content (\%)}

In first year, kalihari, kali musli and safed musli intercrop under Sapota-Jatropha treatment $\left(\mathrm{T}_{1}, 1.086 \%, \mathrm{~T}_{2}, 1.226 \%\right.$ and $\mathrm{T}_{3}, 1.244 \%$ ) noted maximum content of nitrogen (Table 4). The same trend of data was revealed in second year and in pooled analysis.

\subsubsection{Phosphorus content (\%)}

The data depicted in Table 4 indicated that the content of phosphorus by tuber crops after the harvest of crops was non-significant under Sapota-Jatropha and sole crops during experimentations and in their mean data.

\subsubsection{Potassium content (\%)}

The total content of potassium by tuber crops at harvest under Sapota-Jatropha and sole crops is exhibited in Table 4. All the tuber intercrops in their sole stand recorded non-significant results with comparison to their respective intercropping systems during study and in their mean data. The content of all these nutrients increased with increased shade. Higher nutrient in intercropping which might be due to lesser weed competition there by higher absorption and utilization. Similar result was reported by Mohsin (2005) in mint and Rao et al. (2004) in nutrient removal in palmarosa and blackgram intercropping system. 


\subsubsection{Calcium content (\%)}

The total content of calcium at harvest of tuber crops of sole crops and grown under Sapota-Jatropha is exhibited in Table 5. All the tuber crops in their intercropping under Sapota-Jatropha and their respective sole cropping differed non-significantly with respect to their calcium.

\subsubsection{Magnesium content (\%)}

The data regarding content of magnesium at harvest under Sapota-Jatropha and sole crop are tabulated in Table 5. The statistical comparison showed that content of magnesium by tuber crops as affected by intercrops and sole crops are found non-significant for both years and in pooled analysis also. The content of all these nutrients increased with increase in shade. Higher nutrient in intercropping which might be due to lesser weed competition there by higher absorption and utilization.

\subsubsection{Iron content (ppm)}

The total content of iron by crops was recorded higher when tuber crops grown under Sapota-Jatropha as compared to sole cropping (Table 6). During first year, kalihari, kali musli and safed musli when grown under Sapota-Jatropha treatment $\left(T_{1}, 123.56 \%, T_{2}, 145.54 \%\right.$ and $\left.T_{3}, 146.43 \%\right)$ noted maximum content of iron. In second year and pooled analysis data showed the similar trend and result of first year.

Table 5: Secondary nutrients content in plant at harvest of tuber crops as influenced by Sapota-Jatropha three-tier agroforestry system

\begin{tabular}{|c|c|c|c|c|c|c|}
\hline \multirow[t]{2}{*}{ Treatment } & \multicolumn{3}{|c|}{ Calcium $\left(\mathrm{mg} \mathrm{kg}^{-1}\right)$} & \multicolumn{3}{|c|}{ Magnesium $\left(\mathrm{mg} \mathrm{kg}^{-1}\right)$} \\
\hline & 2011 & 2012 & Pooled & 2011 & 2012 & Pooled \\
\hline $\mathrm{T}_{1}$ & $1.546(0.26)^{*}$ & $1.548(0.32)^{*}$ & $1.547(0.32)^{*}$ & $0.438(0.23)^{*}$ & $0.440(0.46)^{*}$ & $0.439(0.46)^{*}$ \\
\hline $\mathrm{T}_{2}$ & $1.570(0.06)^{*}$ & $1.571(0.00)^{*}$ & $1.571(0.06)^{*}$ & $0.453(0.22)^{*}$ & $0.454(0.00)^{*}$ & $0.453(0.00)^{*}$ \\
\hline $\mathrm{T}_{3}$ & $1.575(0.06)^{*}$ & $1.576(0.00)^{*}$ & $1.575(0.00)^{*}$ & $0.457(0.44)^{*}$ & $0.459(0.66)^{*}$ & $0.458(0.44)^{*}$ \\
\hline $\mathrm{T}_{4}$ & 1.542 & 1.543 & 1.542 & 0.437 & 0.438 & 0.437 \\
\hline $\mathrm{T}_{5}$ & 1.569 & 1.571 & 1.570 & 0.452 & 0.454 & 0.453 \\
\hline $\mathrm{T}_{6}$ & 1.574 & 1.576 & 1.575 & 0.455 & 0.456 & 0.456 \\
\hline SEm \pm & 0.049 & 0.068 & 0.042 & 0.019 & 0.020 & 0.014 \\
\hline$C D(p=0.05)$ & NS & NS & NS & NS & NS & NS \\
\hline
\end{tabular}

*Figure in parenthesis indicates percentage increases over respective sole cropping

\subsubsection{Manganese content (ppm)}

The data pertaining in Table 6 showed that in first year of study, higher content of manganese was found when kalihari, kali musli and safed musli grown under Sapota-Jatropha $\left(T_{1}\right.$
$45.34 \%, \mathrm{~T}_{2}, 56.76 \%$ and $\mathrm{T}_{3}, 67.54 \%$ ) which statistically at par with sole kalihari, kali musli and safed musli $\left(\mathrm{T}_{4}, 45.30 \%, \mathrm{~T}_{5}\right.$, $56.74 \%$ and $\left.\mathrm{T}_{6}, 67.50 \%\right)$. The mean data of second year and pooled analysis showed the same result and same trend in

\begin{tabular}{|c|c|c|c|c|c|c|c|c|c|c|c|c|}
\hline \multirow{2}{*}{$\begin{array}{l}\text { Treat- } \\
\text { ment }\end{array}$} & \multicolumn{3}{|c|}{ Iron (ppm) } & \multicolumn{3}{|c|}{ Manganese (ppm) } & \multicolumn{3}{|c|}{ Zinc (ppm) } & \multicolumn{3}{|c|}{ Copper (ppm) } \\
\hline & 2011 & 2012 & Pooled & 2011 & 2012 & Pooled & 2011 & 2012 & Pooled & 2011 & 2012 & Pooled \\
\hline $\mathrm{T}_{1}$ & $\begin{array}{l}123.56 \\
(0.02)^{*}\end{array}$ & $\begin{array}{l}124.06 \\
(0.02)^{*}\end{array}$ & $\begin{array}{l}123.81 \\
(0.02)^{*}\end{array}$ & $\begin{array}{c}45.34 \\
(0.09)^{*}\end{array}$ & $\begin{array}{c}45.59 \\
(0.09)^{*}\end{array}$ & $\begin{array}{l}45.47 \\
(0.09)^{*}\end{array}$ & $\begin{array}{c}18.86 \\
(0.11)^{*}\end{array}$ & $\begin{array}{c}19.11 \\
(0.10)^{*}\end{array}$ & $\begin{array}{c}18.99 \\
(0.11)^{*}\end{array}$ & $\begin{array}{c}9.34 \\
(0.21)^{*}\end{array}$ & $\begin{array}{c}9.36 \\
(0.32)^{*}\end{array}$ & $\begin{array}{c}9.35 \\
(0.32)^{*}\end{array}$ \\
\hline $\mathrm{T}_{2}$ & $\begin{array}{l}145.54 \\
(0.03)^{*}\end{array}$ & $\begin{array}{l}145.79 \\
(0.03)^{*}\end{array}$ & $\begin{array}{l}145.67 \\
(0.03)^{*}\end{array}$ & $\begin{array}{c}56.76 \\
(0.04)^{*}\end{array}$ & $\begin{array}{c}57.01 \\
(0.04)^{*}\end{array}$ & $\begin{array}{c}56.89 \\
(0.04)^{*}\end{array}$ & $\begin{array}{c}29.76 \\
(0.07)^{*}\end{array}$ & $\begin{array}{c}30.01 \\
(0.07)^{*}\end{array}$ & $\begin{array}{c}29.89 \\
(0.07)^{*}\end{array}$ & $\begin{array}{c}13.24 \\
(0.30)^{*}\end{array}$ & $\begin{array}{c}13.26 \\
(0.38)^{*}\end{array}$ & $\begin{array}{c}13.25 \\
(0.30)^{*}\end{array}$ \\
\hline $\mathrm{T}_{3}$ & $\begin{array}{l}146.43 \\
(0.01)^{*}\end{array}$ & $\begin{array}{l}146.68 \\
(0.01)^{*}\end{array}$ & $\begin{array}{l}146.56 \\
(0.01)^{*}\end{array}$ & $\begin{array}{c}67.54 \\
(0.06)^{*}\end{array}$ & $\begin{array}{c}67.79 \\
(0.06)^{*}\end{array}$ & $\begin{array}{c}67.67 \\
(0.06)^{*}\end{array}$ & $\begin{array}{c}30.45 \\
(0.16)^{*}\end{array}$ & $\begin{array}{c}30.70 \\
(0.16)^{*}\end{array}$ & $\begin{array}{c}30.58 \\
(0.16)^{*}\end{array}$ & $\begin{array}{c}13.89 \\
(0.29)^{*}\end{array}$ & $\begin{array}{c}13.91 \\
(0.36)^{*}\end{array}$ & $\begin{array}{c}13.90 \\
(0.29)^{*}\end{array}$ \\
\hline $\mathrm{T}_{4}$ & 123.54 & 124.04 & 123.79 & 45.30 & 45.55 & 45.43 & 18.84 & 19.09 & 18.97 & 9.32 & 9.33 & 9.32 \\
\hline $\mathrm{T}_{5}$ & 145.50 & 145.75 & 145.63 & 56.74 & 56.99 & 56.87 & 29.74 & 29.99 & 29.87 & 13.20 & 13.21 & 13.21 \\
\hline $\mathrm{T}_{6}$ & 146.41 & 146.66 & 146.54 & 67.50 & 67.75 & 67.63 & 30.40 & 30.65 & 30.53 & 13.85 & 13.86 & 13.86 \\
\hline SEm \pm & 4.248 & 5.035 & 3.294 & 1.765 & 2.290 & 1.446 & 0.818 & 1.255 & 0.749 & 0.403 & 0.435 & 0.296 \\
\hline$C D$ & 12.80 & 15.17 & 9.51 & 5.32 & 6.90 & 4.18 & 2.46 & 3.78 & 2.16 & 1.21 & 1.31 & 0.86 \\
\hline
\end{tabular}

${ }^{*}$ Figure in parenthesis indicates percentage increases over respective sole cropping 
total content of manganese of all tuber crops (kalihari, kali musli and safed musli) as per the trend of first year result.

\subsubsection{Zinc content (ppm)}

The result summarized in Table 6 indicates that during first year of study kalihari, kali musli and safed musli when grown under Sapota-Jatropha $\left(\mathrm{T}_{1}, 18.86 \%, \mathrm{~T}_{2}, 29.76 \%\right.$ and $\mathrm{T}_{3}, 30.45 \%$, respectively) were observed higher content of zinc. In second year and in pooled analysis, the similar scenario of total zinc content in kalihari, kali musli and safed musli tuber crops were observed as in the case of first year result.

\subsubsection{Copper content (ppm)}

The data (Table 6) regarding copper content during first year indicated that the kalihari, kali musli and safed musli under Sapota-Jatropha treatment $\left(T_{1}, 9.34 \%, T_{2}, 13.24 \%\right.$ and $T_{3}$, $13.89 \%$ ) noted maximum copper content. Further perusal of data revealed in second year and pooled analysis showed the similar trend of first year. All these nutrients are increased with increase in shade probably due to their accumulation under shaded condition. It also may be due to a possible synergistic effect caused by relative shading and due to more contribution of organic matter to the soil by Sapota and Jatropha.

\section{Conclusion}

The organic carbon, N, P, K, Ca, Mg, Fe, Mn, Zn and $\mathrm{Cu}$ in soil were noted higher under Sapota-Jatropha as compared to sole cropping of kalihari, kali musli and safed musli. The trend was observed same in individual year and as well as in pooled analysis. Nutrient contents in plant viz. organic carbon, $\mathrm{N}, \mathrm{P}, \mathrm{K}, \mathrm{Ca}, \mathrm{Mg}, \mathrm{Fe}, \mathrm{Mn}, \mathrm{Zn}$ and $\mathrm{Cu}$ were registered higher under intercropping of kalihari, kali musli and safed musli as compared to sole crop of kalihari, kali musli and safed musli during both the years and pooled analysis.

\section{References}

Aaron, O., Adams, S., 2016. Assessment of soil nutrients under Maize intercropping system involving soyabean. International Research Journal of Agricultural and Food Sciences 1(3), 33-43.

Deng, B., Tammeorg, P., Luukkanen, O., Helenius, J., Starr, M., 2017. Effects of Acacia seyal and biochar on soil properties and sorghum yield in agroforestry systems in South sudan. Agroforestry systems 91(1), 137-148.

Jaimini, S.N., Patel, J.M., Patel, S.B., 2006. Khejri (Prosopis cineraria) based silvipastoral system for dryland areas of North Gujarat. Indian Journal of Forestry 29(2), 129-130.

Kala, C.P., Sajwan, B.S., 2003. Revitalizing Indian Systems of Herbal Medicine by the National Medicinal Plant Board Through Institutional Networking and Capacity Building. Current Science, 193-199.

Kaur, B., Gupta, S.R., Singh, G., 2002. Bioamelioration of a sodic soil by silvopastoral systems in northiwestern
India. Agroforestry System 54, 13-20.

Laloo, R.C., Kharlukhi, L., Jeeva, S., Mishra, B.P., 2000. Status of Medicinal Plants in the Disturbed and Undisturbed Sacred Forest of Meghalaya. Current science 54, 45-49.

Menezes, R.S.C., Salcedo, I.H., Elliott, E.T., 2002. Microclimate and nutrient dynamics in a silvopastoral system of semiarid northeastern Brazil. Agroforestry Systems 56, 27-38.

Mohsin, F., 2005. Effect of litterfall of short-rotation trees on herbage and oil yield of aromatic plants under agroforestry system. Indian Journal of Agroforestry $7(1), 25-31$.

Panse, V.G., Sukhatme, P.V., 1978. Statistical Methods for Agricultural Workers, I.C.A.R., New Delhi.

Qaisar, K.N., Khan, A. P., Khan, M.N., Zaffar, S.N., Mighloo, J.A., 2007. Fodder production in Agricultural system under rainfed condition in Kashmir. Indian Journal of Agroforestry 9(1), 20-22.

Rajesh, T., Baghel, B.S., 2014. Effect of intercropping on plant and soil of dashehari mango orchard under low productive environmental. The Asian Journal of Horticulture 9(2), 439-442.

Rao, M. R., Palada, M.C., Becker, B.N., 2004. Medicinal and aromatic plants in agroforestry systems. Agroforestry Systems 61, 107-122.

Samritika, T., Kumar, B.M., Kunhamu, T.K., 2015. Coarse root biomass, carbon and nutrient stock dynamics of different stem and crown classes of silver oak (Grevillea robusta A. Cunn. Ex. R. Br.) plantation in Central Kerala, India. Agroforestry system 89(5), 869-883.

Shehnaz, S., Singh, B., Sikha, R., 2015. Soil organic carbon and nitrogen pools in a chronosequence of poplar (Populus deltoides) plantations in alluvial soils of Punjab, India. Agroforestry system 89(6), 1049-1063.

Shinde, S.B., 2001. Effect of forest tree species on the growth and production of forage crops. M.Sc. (Agroforestry). A thesis submitted to the G.A.U., S.K. Nagar.

Vanlalhluna, P.C., Sahoo, U.K., 2010. Tree growth and crop yield under agroforestry practices in Mizoram. N.E. India. Journal of Tropical Forestry 26(2), 49-54.

Venugopal, C.K., Mokashi A.N., Jholgiker, P., 2008. Studies on comparative performance of patchouli (Pogostemon patchouli Benth.) under open and partial shade ecosystem. Journal of Medicinal and Aromatic Plant Science 30, 22-26.

Willey, R.W., 1979. Intercropping - its importance and research needs. Part-I, Competition and yield advantages. Field Crop Abstract 32, 1-10.

Xue, Y., Xia, H., Christie, P., Zheng, Z., Li, L., Tang, C., 2016. Crop acquisition of phosphorus, Iron and Zinc from soil in cereal/legume intercropping systems: a critical review. Annals of Botany 117(3), 363-377. 